\title{
KAJIAN EVALUASI KINERJA INVESTASI KABUPATEN GARUT
}

\author{
Oleh : \\ Dadang Syafarudin \\ Jajang Sugiat
}

\begin{abstract}
Program Studi Manajemen S1, STIE Yasa Anggana Garut
Email: dadangsya@ stieyasaanggana.ac.id

Program Studi Manajemen S1, STIE Yasa Anggana Garut

Email: jajangya@stieyasaanggana.ac.id

DOI Artikel : https://doi.org/10.34308/eqien.v6i2.100
\end{abstract}

\section{Article Info}

Article History :

Received 19 Agustus 2019

Accepted 02 September 2019

Available Online 09 September 2019

Keyword :

Garut Regency, Investment,

Regional Government

\begin{abstract}
Based on the National Spatial Planning and Spatial Planning of West Java Province in 2010, the role of Garut Regency is related to the spatial structure policy of the West Java region which sets two regional categories, namely the main area and the supporting area, in this case the Garut Regency as the central supporting region support economic growth in the main region together with the regions of Sukabumi and Cianjur Regencies. In the Provincial Spatial Planning plan that shows the dominant allocation of economic activity, Garut Regency is allocated for dry land agriculture activities, production forests, plantations, and fisheries. Investment Development Policy in Garut Regency is stipulated in the Regional Regulation of Garut Regency Number 14 of 2012 Regarding Investment Chapter III Direction of Investment Policy in the Region.

The purpose of the Garut Regency Regional Investment Performance Evaluation Study is to provide convenience for the Regional Government in this case the Integrated Investment and Licensing Office and various other parties such as the general public, prospective investors in determinin $g$ the choice of various alternative investment opportunities. the methodology to be carried out in the Garut Regency Investment Performance Evaluation Study, carried out several analyzes. These analyzes can be seen from the potential conditions (natural resources, human resources), supporting infrastructure, policies and economic conditions in the area around the Garut Regency Investment Area.
\end{abstract}

\section{PENDAHULUAN}

Pembangunan daerah dimaksudkan untuk mendorong, memberdayakan masyarakat, menumbuhkan prakarsa serta meningkatkan partisipasi masyarakat dalam rangka membangun daerahnya, dan meningkatkan kesejahteraan masyarakat. Pembangunan yang dilaksanakan daerah meliputi berbagai bidang, salah satunya pembangunan ekonomi. Arsyad (1999) mengemukakan bahwa 
“........pembangunan ekonomi daerah adalah suatu proses dimana pemerintah daerah dan masyarakat mengelola sumberdaya yang ada dan membentuk suatu pola kemitraan antara pemerintah daerah dengan sektor swasta untuk menciptakan lapangan kerja baru dan merangsang perkembangan kegiatan ekonomi (pertumbuhan ekonomi) dalam wilayah tersebut". Menurut Sukirno (1996) pertumbuhan dan pembangunan ekonomi memiliki definisi yang berbeda, yaitu pertumbuhan ekonomi ialah proses kenaikan output perkapita yang terus menerus dalam jangka panjang. Pertumbuhan ekonomi tersebut merupakan salah satu indikator keberhasilan pembangunan. Dengan demikian makin tingginya pertumbuhan ekonomi biasanya makin tinggi pula kesejahteraan masyarakat, meskipun terdapat indikator yang lain yaitu distribusi pendapatan.

Investasi mempunyai peranan yang penting sekali, karena tidak ada investasi berarti tidak ada pembangunan, sehingga sasaran suatu pembangunan akan dapat dicapai apabila ada investasi yang dilakukan. Sebelum suatu investasi dilakukan harus dikaji secara mendalam, karena biasanya membutuhkan biaya yang cukup besar dan hasilnya baru dapat dirasakan pada tahun-tahun pertama. Kegagalan suatu investasi yang tidak mencapai sasaran yang diinginkan berarti kegagalan pula dalam perencanaan pembangunan karena Investasi adalah salah satu faktor yang memberikan perubahan sosial, ekonomi, budaya dan Pendidikan.

Kabupaten Garut merupakan sebagai salah satu Kabupaten yang cukup strategis, berada 60 $\mathrm{Km}$ di Wilayah Selatan Jawa Barat yang memiliki potensi sumber daya alam yang besar, Pemerintah Daerah Kabupaten Garut menyadari bahwa investasi memiliki peran yang sangat penting untuk bisa menggerakan perekonomian daerah / lokal. Kegiatan investasi, berdampak pada laju pertumbuhan ekonomi suatu daerah yang pada gilirannya akan mempengaruhi pula kinerja ekonomi daerah dengan penciptaan lapangan kerja baru yang akan mempertinggi pula kinerja ekonomi daerah serta mempertinggi daya beli masyarakat dan juga menekan angka kemiskinan.
Berdasarkan data minat investasi di Kabupaten Garut tahun 2016-2017 menunjukkan bahwa minat investasi di Kabupaten Garut menunjukkan adanya peningkatan seperti pada tahun 2016 pada Sektor Primer/Primary Sector sebesar Rp. 20.000.000.000 meningkat pada tahun 2017 menjadi Rp. 252.440.301.000 sedangkan pada Sektor Tersier/Tertiary Sector tahun 2016 3.314.209.718.857 menurun pada tahun 2017 menjadi Rp. 2.776.100.543.710 dan Sektor Sekunder/ Secondary Sector tahun 2017 608.205.440.00o, namun secara keseluruhan tahun 2016 sebesar Rp. 3.334.209.718.857 meningkat tahun 2017 menjadi Rp. 3.636.746.284.710.

\section{Maksud dan Tujuan Penelitian}

Maksud dilaksanakannya kegiatan Evaluasi Kinerja Investasi Daerah Kabupaten Garut adalah untuk menyajikan informasi terkait dengan pelaksanakan kinerja investasi yang berdampak pada pengembangan ekonomi lokal dan serta peluang pengembangan investasi di masa yang akan datang sehingga berguna bagi Pemerintah Daerah Kabupaten Garut maupun bagi stakeholder lainnya.

Sedangkan tujuan kegiatan Evaluasi Kinerja Investasi Daerah Kabupaten Garut adalah untuk memberikan kemudahan bagi Pemerintah Daerah Kabupaten Garut dalam hal ini Dinas Penanam Modal dan Perijinan Terpadu serta berbagai pihak-pihak lainnya seperti masyarakat umum, calon investor dalam menentukan pilihan dari berbagai alternatif peluang investasi

\section{KAJIAN PUSTAKA DAN PEGEMBANGAN HIPOTESIS}

Agenda pembangunan di dalam RPJMN 2015-2019 telah memasukkan arahan agenda prioritas. Arahan agenda prioritas NAWACITA yang menjadi bagian utama dalam agenda pembangunan adalah dengan meningkatkan produktivitas rakyat dan daya saing di pasar internasional (NAWACITA 6) serta mewujudkan kemandirian ekonomi dengan menggerakan sektorsektor strategis ekonomi domestik (NAWACITA 7). Kebijakan pengembangan wilayah menjadi salah satu instrumen atau cara untuk mengatasi masalah dan mengoptimalkan potensi daerah, mengurangi kesenjangan antar daerah, mendorong percepatan pembangunan daerah 
dan mengembangkan daya saing dan keunggulan daerah.

Keunggulan daerah terbagi menjadi dua, yaitu keunggulan komparatif dan kompetitif guna meningkatkan daya saing. Keunggulan komparatif daerah dipengaruhi oleh (i) kondisi geografis dan sumber daya alam yang dikelola dengan baik; (ii) penduduk, angkatan kerja dan tenaga kerja terdidik; (iii) infrastruktur yang modern dan merata; dan (iv) kondisi ketertiban dan keamanan daerah yang stabil. Sejalan dengan keunggulan komparatif, terdapat keunggulan kompetitif daerah yang perlu dipertimbangkan dan ditentukan oleh (i) produksi dan jasa berstandar internasional; (ii) produksi dan jasa berstandar internasional; (ii) iklim investasi dan iklim usaha yang mendukung; (iii) birokrasi yang lebih baik; (iv) kebijakan pemerintah daerah yang terukur dan jelas; (v) jejaring dan promosi internasional; dan (vi) kerjasama antara pemerintah, swasta dan perguruan tinggi.

Salah satu peningkatan daya saing daerah adalah dengan adanya investasi sebagai bagian dari komponen PDB. Investasi adalah penanaman modal untuk satu atau lebih aktiva yang dimiliki dan biasanya berjangka waktu lama dengan harapan mendapatkan keuntungan di masa-masa yang akan datang (Sunariyah, 2003:4). Investasi adalah menempatkan uang atau dana dengan harapan untuk memperoleh tambahan atau keuntungan tertentu atas uang dana tersebut (Ahmad, 2004). Menurut Samuelson (2004: 198), investasi meliputi penambahan stok modal atau barang disuatu negara, seperti bangunan peralatan produksi, dan barang-barang inventaris dalam waktu satu tahun.

Berdasarkan beberapa pengertian diatas, maka dapat disimpulkan bahwasanya investasi atau penanaman modal merupakan pengeluaran atau pembelanjaan yang dapat berupa jenis barang modal, bangunan, peralatan modal, dan barang-barang inventaris yang digunakan untuk menambah kemampuan memproduksi barang dan jasa atau untuk meningkatkan produktiktivitas kerja sehingga terjadi peningkatan output yang dihasilkan dan tersedia untuk masyarakat.

Dalam teori investasi, dikemukakan bahwa Dalam jangka panjang pertumbuhan investasi berpengaruh pada bertambahnya stok capital dan selanjutnya menaikan produktivitas. Teori Neo Klasik menekankan pentingnya tabungan sebagai sumber investasi. Investasi dipandang sebagai salah satu penggerak utama pertumbuhan ekonomi dan pembangunan. Tokoh Neo Klasisk, Sollow dan Swan memusatkan perhatiannya pada bagaimana pertumbuhan penduduk, akumulasi capital, kemajuan teknologi dan output saling berinteraksi dalam proses pertumbuhan ekonomi (Arsyad, 2010: 88-89).

Teori Harrod-Domar memandang bahwa pembentukan modal dianggap sebagai pengeluaran yang akan menambah kemampuan suatu perekonomian untuk menghasilkan barang dan atau jasa, maupun sebagai pengeluaran yang akan menambah permintaan efektif seluruh masyarakat. Dimana apabila pada suatu masa tertentu dilakukan sejumlah pembentukan modal, maka pada masa berikutnya perekonomian tersebut mempunyai kemapuan untuk menghasilkan barang-barang dan atau jasa yang lebih besar (Sadono, 2007: 256-257).

Sedangkan Menurut Peraturan Pemerintah No. 24 Tahun 2005, Investasi adalah penempatan sejumlah dana dan/atau barang oleh pemerintah pusat dalam jangka panjang untuk investasi pembelian surat berharga dan investasi langsung, yang mampu mengembalikan nilai pokok ditambah dengan manfaat ekonomi, sosial, dan/atau manfaat lainnya dalam jangka waktu tertentu. Faktor faktor penentu pertumbuhan ekonomi menutut Kznets (1969) yaitu:

1) Kenaikan pendapatan perkapita riil.

2) Distribusi angkatan kerja menurut sektor kegiatan produksi yang merata.

Sementara dari pendekatan investasi, Sumantoro (1983) mendefinisikan tujuan investasi ditinjau atas dasar kepentingan investor dan kepentingan pemerintah. Tujuan investasi dari kepentingan investor berorientasi ekonomis yaitu; kesempatan berusaha untuk memperoleh keuntungan, menanamkan modal dengan harapan memperoleh nilai tambah yang lebih besar dari modal yang ditanamkan, berusaha menjaga sekaligus menghindar dari kerugian yang disebabkan oleh merosotnya nilai uang. Sedangkan tujuan investasi dilihat dari kepentingan pemerintah melibatkan kepentingan masyarakat luas, baik individu 
maupun pihak swasta nasional maupun swasta asing. Investasi diarahkan untuk pembiayaan kegiatan pembangunan secara makro terkait dengan public utility.

Berdasarkan jenisnya investasi dibagi menjadi dua jenis, yaitu: Pertama investasi pemerintah, adalah investasi yang dilakukan oleh pemerintah pusat maupun pemerintah daerah. Kedua investasi swasta, adalah investasi yang dilakukan oleh sektor swasta nasional yaitu Penanaman Modal Dalam Negeri (PMDN) ataupun investasi yang dilakukan oleh swasta asing atau disebut Penanaman Modal Asing (PMA). Salvatore (1997) menjelaskan bahwa PMA terdiri atas:

a. Investasi portofolio (portfolio investment), yakni investasi yang melibatkan hanya aset-aset finansial saja, seperti obligasi dan saham, yang didenominasikan atau ternilai dalam mata uang nasional. Kegiatankegiatan investasi portofolio atau finansial ini biasanya berlangsung melalui lembagalembaga keuangan seperti bank, perusahaan dana investasi, yayasan pensiun, dan sebagainya.

b. Investasi asing langsung (Foreign Direct Investment), merupakan PMA yang meliputi investasi ke dalam aset-aset secara nyata berupa pembangunan pabrikpabrik, pengadaan berbagai macam barang modal, pembelian tanah untuk keperluan produksi, dan sebagainya.

Kemudian berdasarkan pendekatan tipe investasi, menurut Jogiyanto (2003), investasi ke dalam aktiva keuangan dapat berupa investasi langsung dan investasi tidak langsung.

a. Investasi Langsung : Investasi langsung dapat dilakukan dengan membeli aktiva keuangan yang dapat diperjual-belikan di pasar uang (money market), pasar modal (capital market), atau pasar turunan (derivative market). Pasar uang bersifat untuk jangka pendek karena aktiva yang dapat diperjual-belikan di pasar uang berupa aktiva yang mempunyai risiko gagal kecil. Salah satu contohnya adalah sertifikat deposito yang dapat dinegosiasi (dapat dijual kembali). Berbeda dengan pasar uang, pasar modal lebih bersifat untuk investasi jangka panjang. Yang diperjual-belikan di pasar modal adalah aktiva keuangan berupa surat-surat berharga pendapatan tetap (fixed-income securities) dan saham-saham (securities). Surat-surat berharga yang dapat diperdagangkan di pasar turunan (derivative market) adalah opsi (option) dan future contract. Disebut dengan suratsurat berharga turunan karena nilainya merupakan jabaran dari surat berharga lain yang terkait. Contoh dari opsi (option) misalnya adalah waran (warrant).

b. Investasi Tidak Langsung : Investasi tidak langsung dilakukan dengan membeli surat-surat berharga dari perusahaan investasi. Perusahaan investasi adalah perusahaan yang menyediakan jasa keuangan dengan cara menjual sahamnya ke publik dan menggunakan dana yang diperoleh untuk diinvestasikan ke dalam portofolionya.

Menurut Tandelilin (2010) ada beberapa alasan mengapa seseorang melakukan investasi, antara lain sebagai berikut:

a. Untuk mendapatkan kehidupan yang lebih layak di masa datang. Seseorang yang bijaksana akan berfikir bagaimana meningkatkan taraf hidupnya dari waktu ke waktu atau setidaknya berusaha bagaimana mempertahankan tingkat pendapatannya yang ada sekarang agar tidak berkurang di masa yang akan datang.

b. Mengurangi tekanan inflasi. Dengan melakukan investasi dalam pemilikan perusahaan atau obyek lain, seseorang dapat menghindarkan diri dari risiko penurunan nilai kekayaan atau hak miliknya akibat adanya pengaruh inflasi

1. Dorongan untuk menghemat pajak. Beberapa negara di dunia banyak melakukan kebijakan yang bersifat mendorong tumbuhnya investasi di masyarakat melalui pemberian fasilitas perpajakan kepada masyarakat yang melakukan investasi pada bidang-bidang usaha tertentu.. 


\section{METODE PENELITIAN}

Pendekatan pada kegiatan Kajian Evaluasi Kinerja Investasi Kabupaten Garut dilakukan melalui beberapa pendekatan kegiatan, yaitu,

a. Pendekatan Kesatu adalah pendekatan studi literatur (desk study), terhadap kebijakankebijakan dan teori-teori untuk mendukung terhadap Kajian Evaluasi Kinerja Investasi Kabupaten Garut.

b. Pendekatan kedua adalah pengumpulan data baik primer maupun sekunder

c. Pendekatan ketiga adalah pendekatan secara analisis setelah mendapatkan seluruh data primer dan sekunder. Pendekatan analisis yang digunakan adalah analisis potensi, analisis infrastruktur, analisis kebutuhan investasi, analisis stakeholder, analisis dampak, analisis kebijakan dan analisis pendukung (sosial-ekonomi) dan analisis trend investasi.

d. Pendekatan keempat adalah FGD (Forum Group Discution) dan sosialisasi yang dilakukan di beberapa wilayah studi dengan mengundang stakeholders terkait

Dalam kajian / penelitian ini yang menjadi objek adalah sektor :

a) Sektor Pembangkit Listrik Tenaga Mikro Hidro,

b) Sektor Pariwisata

Teknik pengumpulan data, menurut Suharsimi Arikunto (2010:265), instrumen pengumpulan data adalah alat bantu yang dipilih dan digunakan oleh peneliti dalam kegiatannya mengumpulkan data agar kegiatan tersebut menjadi sistematis dan dipermudah olehnya diantaranya adalah, wawancara, observasi partisipasi, dokumenter, penelusuran online, survey atau field research dan forum group discussion (FGD).

Metoda analisis yang digunakan adalah analisis kuantitatif analisis prioritas masalah dan analisis keterkaitan. Analisis kuantitatif dengan menggunakan berbagai indikator pembangunan seperti pertumbuhan ekonomi, Pembangunan Manusia, infrastruktur, PDRB sectoral, pendapatan per kapita, kemiskinan, pengangguran, Indeks pemerataan antar daerah, dan indikator pembangunan sosial, lingkungan dan lainnya,

\section{HASIL DAN PEMBAHASAN}

Evaluasi kinerja investasi daerah kabupaten Garut. Untuk menganalisa data secara kuantitatif, maka peneliti mengkaji menggunakan berbagai indikator yang hasilnya ditampilkan dalam trend perkembangan investasi daerah kabupaten Garut.

\section{Trend Sektor Pembangkit Tenaga Listrik}

Minat Investasi Tahun 2013 - 2017

TABEL 1

Perkembangan Minat Investasi Sektor Pembangkit Listrik, Gas dan AIr 5 Tahun Terakhir

\begin{tabular}{|c|c|c|}
\hline Tahun & Sektor Listrik, Gas dan Air & Kenaikan \\
\hline 2013 & 413.045 .555 .505 & \\
\hline 2014 & 811.111 .465 .685 & $96 \%$ \\
\hline 2015 & 449.052 .707 .000 & $-45 \%$ \\
\hline 2016 & 2.356 .725 .000 .000 & $425 \%$ \\
\hline 2017 & 953.923 .674 .746 & $-60 \%$ \\
\hline Jumlah & 4.983 .858 .402 .936 & \\
\hline
\end{tabular}

(Sumber :Dinas Penanaman Modal dan Perizinan Terpadu Kab. Garut)

Dari Tabel diatas terlihat bahwa minat investasi sektor Pembangkait Tenaga Listrik di Kabupaten Garut belum berjalan sebagaimana mestinya walaupun potensi yang di miliki Kabupaten garut Sangat mendukung untuk di lakukan investasi pada sector ini, terlihat dari data diatas pada tahun 2014 terjadinya kenaikan sebesar 811.111.465.685 (96\%) pada tahun 2015 terjadi penurunan 449.052.707.000 (45\%), pada tahun 2016 Naik menjadi 2.356.725.000.000 (425\%) dan pada tahun 2017 turun $953.923 .674 .746(-60 \%)$.

\section{Kinerja / Realisasi Investasi Tahun 2013 - 2017}

TABEL 2

Perkembangan Realisasi Investasi Sektor Listrik, Gas dan Air 5 Tahun Terakhir

\begin{tabular}{|c|c|c|}
\hline Tahun & Sektor Listrik, Gas dan Air & Kenaikan \\
\hline 2013 & 110.845 .830 .415 & \\
\hline 2014 & 359.901 .706 .933 & $225 \%$ \\
\hline 2015 & 198.175 .095 .725 & $-45 \%$ \\
\hline 2016 & 262.394 .118 .515 & $32 \%$ \\
\hline 2017 & 486.467 .384 .607 & $85 \%$ \\
\hline Jumlah & 1.47 .784 .136 .195 & \\
\hline
\end{tabular}

Berdasarkan tabel di atas dapat kita lihat bahwa Perkembangan Realisasi Investasi Sektor Listrik, Gas dan Air 5 Tahun Terakhir dari sisi nilai mengalami kenaikan walaupun angka dari 2013 s.d. 2015 berfluktuasi, realisasi terbesar terdapat kenaikan pada tahun 2014 sebesar $225 \%$ dibandingkan dengan tahun sebelumnya 2013, dan di akhir tahun laporan 2017 tercatat 
realisasi sebesar Rp. 4.86.467.384.607 mengalami kenaikan 85\% dari tahun 2016. Untuk melihat adanya trend kenaikan realisasi sektor listrik, gas dan air ditampilkan dalam grafik berikut ;

\section{GRAFIK 1}

Perkembangan Minat Investasi Sektor Pembangkit Listrik Tenaga

Mikro Hidro, Pembangkit Listrik Tenaga Geotermal 5 Tahun Terakhir Tahun Sektor Listrik, gas dan Air

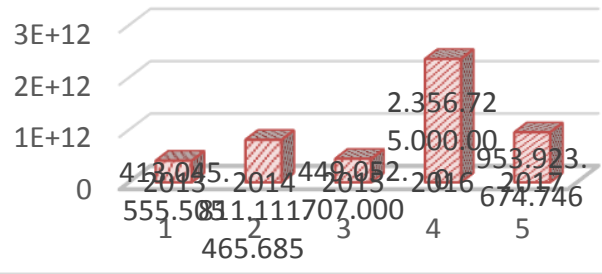

( Sumber : Dinas Penanaman Modal dan Perizinan Terpadu Kab. Garut )

\section{Trend Sektor Pariwisata (Hotel dan Restoran) \\ Minat Investasi Tahun 2013 - 2017}

Kabupaten Garut Salah satu kabupaten di Jawa Barat yang mengembangkan perekonomian di bidang Pariwisata dalam hal ini Bidang Perhotelan dan restoran. Pengukuran efektivitas sektor kepariwisataan di Kabupaten Garut bisa dilihat dari : Perkembangan Minat Investasi sektor Pariwisata 5 tahun terakhir terlihat dari tabel 3 sebagai berikut :

TABEL 3

Perkembangan Minat Investasi Sektor Pariwisata 5 Tahun Terakhir ( Hotel dan Restoran )

\begin{tabular}{|c|c|c|}
\hline Tahun & Sektor Wisata & Kenaikan \\
\hline 2013 & 46.300 .000 .000 & \\
\hline 2014 & 49.500 .000 .000 & $7 \%$ \\
\hline 2015 & 57.357 .144 .000 & $16 \%$ \\
\hline 2016 & 202.264 .000 .000 & $253 \%$ \\
\hline 2017 & 99.415 .987 .500 & $-51 \%$ \\
\hline Jumlah & 454.837.131.500 & \\
\hline
\end{tabular}

(Sumber :Dinas Penanaman Modal dan Perizinan Terpadu Kab. Garut)

Dari tabel diatas terlihat bahwa realisasi investasi Sektor pariwisata pada 5 tahun terakhir khususnya sektor Hotel dan restoran cukup menjanjikan terutama pada tahun 2017, pada tahun 2013 sektor wisata sebesar 32.826.951.473 terjadi kenaikan pada tahun 2014 54.667.502.067 (67\%) tapi pada tahun
2015 mengalami penurunan sebesar 20.154.000.000 (65\%) pada tahun 2016 Naik menjadi 20.154.000.000 (7\%) dan pada tahun 2017 naik signifikan 63.247.966.493 (214\%). Lebih jelasnya Turun Naik dari Realisasi Investasi Sektor Pariwisata 5 Tahun Terakhir Hotel dan Restoran di Kabupaten Garut, realisasi investasi Sektor Pariwisata pada 5 Tahun terakhir di Kabupaten Garut sudah berjalan baik sehingga dengan Realisasi Investasi tersebut dapat memberikan manfaat bagi kabupaten Garut diantaranya,

terwujudnya iklim investasi yang sehat melalui reformasi kelembagaan ekonomi di berbagai tingkatan pemerintahan sehingga mampu meningkatkan investasi sekitar $6,52 \%$ persen, serta meningkatnya citra Kabupaten Garut sebagai salah satu Kabupaten tujuan investasi yang menarik dan minat investasi di Indonesia, terjadinya peningkatan jumlah wisatawan lokal maupun mancanegara sehingga berdampak pada peningkatan Anggaran Pendapatan Belanja Daerah dan ekonomi masyarakat dari kegiatan perjalanan wisatawan.

GRAFIK 2

Perkembangan Minat Investasi Sektor Pariwisata 5 Tahun Terakhir

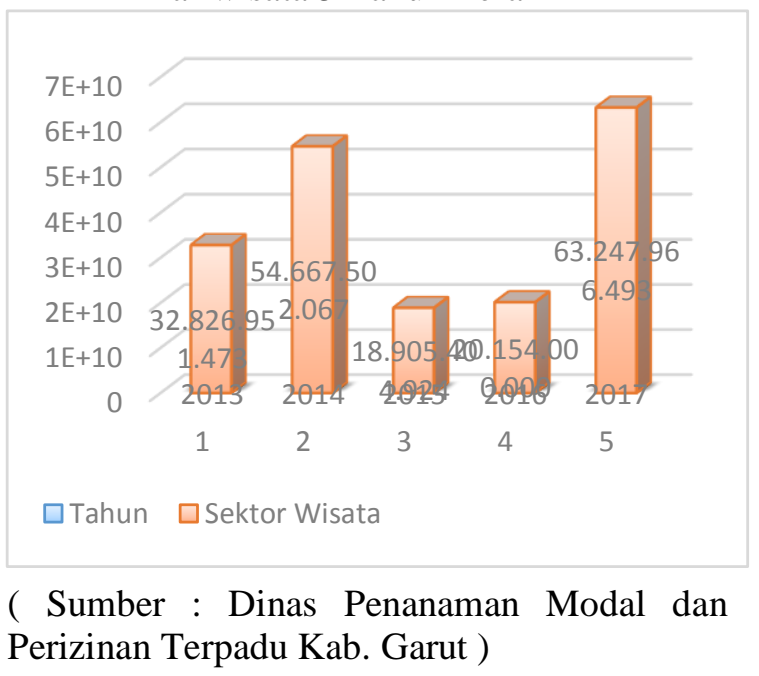

\section{Kinerja / Realisasi Investasi Tahun 2013 - 2017}

Realisasi investasi Sektor Pariwisata pada 5 Tahun terakhir di Kabupaten Garut sudah berjalan baik sehingga dengan Realisasi Investasi tersebut dapat memberikan manfaat bagi kabupaten Garut diantaranya, terwujudnya iklim investasi yang sehat melalui reformasi kelembagaan ekonomi di berbagai tingkatan pemerintah sehingga mampu meningkatkan investasi sekitar 6,52\%. Dari tabel terlihat 
bahwa realisasi investasi Sektor pariwisata pada 5 tahun terakhir khususnya sektor Hotel dan restoran cukup menjajikan terutama pada tahun 2017, pada tahun 2013 sektor wisata sebesar 32.826.951.473 terjadi kenaikan pada tahun 2014 54.667.502.067 (67\%) tapi pada tahun 2015 mengalami penurunan sebesar 20.154.000.000.

TABEL 4

Perkembangan Realisasi Investasi Sektor Pariwisata 5 Tahun Terakhir

\begin{tabular}{|c|c|c|}
\hline Tahun & Sektor Wisata & Kenaikan \\
\hline 2013 & 32.826 .951 .473 & \\
\hline 2014 & 54.667 .502 .067 & $67 \%$ \\
\hline 2015 & 18.905.404.924 & $-65 \%$ \\
\hline 2016 & 20.154 .000 .000 & $7 \%$ \\
\hline 2017 & 63.247 .966 .493 & $214 \%$ \\
\hline Jumlah & 189.801 .824 .957 & \\
\hline
\end{tabular}

(Sumber :Dinas Penanaman Modal dan Perizinan Terpadu Kab. Garut)

\section{Trend Sektor Padat Karya (Sekunder) Minat Investasi Tahun 2013 - 2017}

TABEL5

Perkembangan Minat Investasi Sektor Padat Karya /Sekunder 5 Tahun Terakhir

\begin{tabular}{|c|c|c|}
\hline Tahun & Sektor Padat Karya & Kenaikan \\
\hline 2013 & 2.000 .000 .000 & \\
\hline 2014 & 117.000 .000 .000 & $5750 \%$ \\
\hline 2015 & 99.469 .000 .000 & $-15 \%$ \\
\hline 2016 & - & $-100 \%$ \\
\hline 2017 & 608.205 .440 .000 & $60800 \%$ \\
\hline Jumlah & 826.674 .440 .000 & \\
\hline
\end{tabular}

(Sumber :Dinas Penanaman Modal dan Perizinan Terpadu Kab. Garut)

Dari tabel diatas terlihat bahwa perkembangan minat Investasi Sektor Padat karya pada 5 Tahun terakhir di Kabupaten Garut mengalami fluktuatif khususnya pada tahun 2014 sebesar 117.000.000.000 (5750\%) mengalami penurunan pada Tahun 2015 menjadi 99.469.000.000 (-15\%) pada tahun 2016 tidak terjadi Investasi di sector ini tetapi pada tahun 2017 sebesar 608.205.440.000 (60800\%).

\section{Kinerja / Realisasi Investasi Tahun 2013 - 2017}

Dari grafik dibawah menunjukkan bahwa Realisasi Investasi Sektor Padat karya pada 5 Tahun terakhir mengalami fluktuasi seperti terlihat pada tabel diatas bahwa pada tahun
2014 mengalami kenaikan menjadi 55.833.373.795 (1015\%), pada tahun 2015 mengalami kenaikan menjadi 379.419.515.932 (580\%), namun pada tahun2016 Mengalami penurunan menjadi 68.679.781.087 (-82\%) dan Pada tahun 2017 naik kembali 299.228.807.603 (336\%). Ini menunjukan bahwa gairah Investasi di Kabupaten Garut tidak hanya terbatas pada sektor pariwisata melainkan pada sektor lain yang memang menjadi Unggulan di Kabupaten Garut salahsatunya Investasi Padat Karya dengan berdirinya pabrik-pabrik yang bergerak di bidang produksi yang dapat menyerap tenaga kerja lebih bannyak seperti Changsin yang memproduksi sepatu dengan jumlah karyawan kurang lebih 5.500 orang serta pabrik yang sejenis.

GRAFIK 3

Perkembangan Minat Investasi Sektor Padat Karya /Sekunder 5 Tahun Terakhir

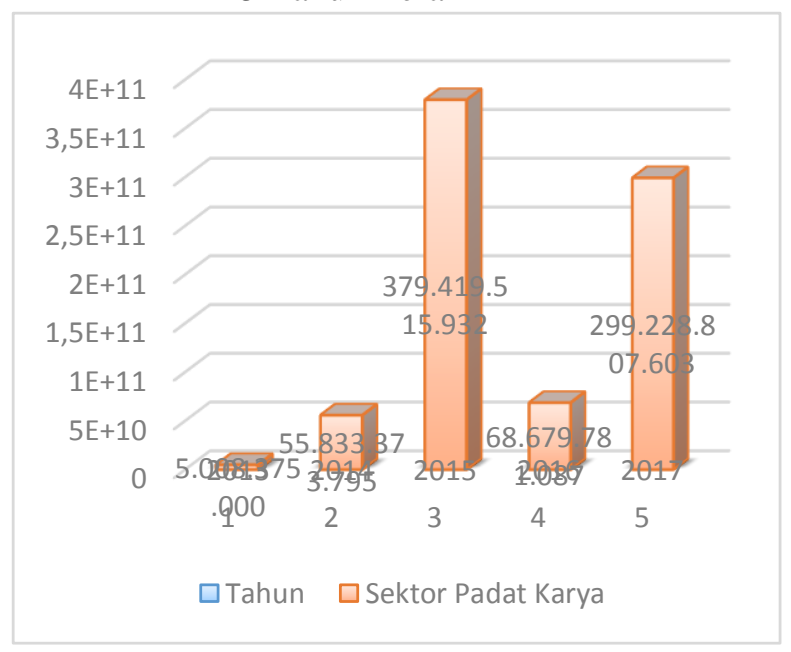

( Sumber : Dinas Penanaman Modal dan Perizinan Terpadu Kab. Garut )

\section{SIMPULAN DAN SARAN}

1. Penguatan struktur perekonomian Kabupaten Garut harus tetap focus pada infestasi sektor pariwisata, sektor Pembangkit Listrik Tenaga Mikro Hidro dan Sektor Padat Karya. Karena sektor ini mampu menggalakan kegiatan ekonomi masyarakat, termasuk kegiatan sektor lain yang terkait, sehingga membuka lapangan kerja, meningkatkan pendapatan masyarakat, pendapatan daerah, dan pada akhirnya berkontribusi terhadap pendapatan negara serta penerimaan devisa melalui 
pengembangan dan pendayagunaan berbagai potensi yang dimilikinya.

2. Berdasarkan potensi Perkembangan Investasi Sektor Pembangkit Listrik Tenaga Mikro Hidro 5 Tahun mendatang, harus menjadi prioritas karena banyak memberi manfaat bagi masyarakat antara lain digunakannya energi terbarukan yang ramah lingkungan, menyerap Jumlah sumber daya manusia, meningkatkan kegiatan perekonomian sehingga diharapkan dapat menambah penghasilan masyarakat, menjadi energi alternatif pengganti listrik untuk penerangan, dan kedepan dapat menjadi salah satu sumber Pendapatan Asli Desa.

3. Berdasarkan potensi Perkembangan Investasi Sektor Pariwisata khususnya hotel dan restoran Kabupaten Garut memiliki potensi yang sangat besar untuk Perkembangan Investasi pada Sektor ini, khususnya pada pada bidang hotel dan restoran. Sehingga Kabupaten Garut harus tetap membuka seluas luasnya investasi dengan tetap mengacu pada Rencana Tata Ruang sektor ini.

4. Perkembangan Investasi Sektor Padat Karya di Kabupaten Garut mengalami peningkatan dan memiliki potensi besar juga untuk berkembang dan maju. Investasi pada sektor padat karya cukup signifikan dalam menekan angka penggangguran di Kabupaten Garut, sehingga berpotensi untuk terus dikembangkan sebagai rujukan untuk meningkatkan struktur ekonomi kabupaten Garut lebih baik

\section{REFERENSI}

Eni Setyowati dan Siti Fatimah. 2007. Analisis Faktor-Faktor yang Mempengaruhi Investasi Dalam Negeri di Jawa Tengah 1980-2002. Jurnal Ekonomi Pembangunan

Arsyad, Lincolin. 1999. Pengantar Perencanaan Dan Pembangunan Ekonomi Daerah. BPFE :Yogyakarta.

Sukirno, Sadono. 1996. Pengantar Teori Makro Ekonomi. PT Raja Grafindo : Jakarta.

A Samuelson, dkk. 2004. Ilmu Makro Ekonomi. PT Media Global Edukasi : Jakarta.

Tarigan, Robinson. 2004. Perencanaan Pembangunan Wilayah. PT Bumi Aksara : Jakarta.
Sumantoro. 1983. Peranan Perusahaan Multinasional Dalam Pembangunan Negara Sedang Berkembang dan Implikasinyadi Indonesia. Penerbit Alumni : Bandung.

Jogiyanto. 2003. Teori Portofolio dan Analisis Investasi, Edisi Ketiga. BPFE : Yogyakarta.

Aduardus, Tandelilin. 2010. Fortofolio dan Investasi. Konisius : Yogyakarta.

Alam, Purnama, Haris A. 2004. Konsep Penulisan Laporan Ilmiah (Format dan Gaya). YIM Press : Bandung

Arikunto. 2006. Prosedur Penelitian. Rineka Cipta : Jakarta

Bungin, Burhan. 2010. Penelitian Kualitatif. Kencana : Jakarta

Efendi, Sofian dan Singarimbun, Masri. 1995. Metode Penelitian Survai. LP3ES : Jakarta

http://www.garutkab.go.id/

Nazir, Moch. 1988. Metode Penelitian. Ghalia Indonesia : Bogor. 2005. Metode Penelitian. Ghalia Indonesi : Bogor

Sugiyono. 2009. Metode Penelitian Bisnis (Pendekatan Kuantitatif, Kualitatif dan $R \& D)$. ALfabeta : Bandung

Undang Undang Republik Indonesia Nomro 23 Tahun 2014 Tentang Pemerintahan Daerah

Undang Undang Republik Indonesia Nomor 25 Tahun 2007 Tentang Penanaman Modal

Peraturan Pemerintah No. 24 Tahun 2005

Peraturan Pemerintah Republik Indonesia Nomor 18 Tahun 2016 Tentang Perangkat Daerah.

Peraturan Pemerintah Nomor 26 Tahun 2008 tentang Rencana Tata Ruang Wilayah Nasional; Rencana Tata Ruang Wilayah (RTRW) Nasional

Peraturan Daerah Nomor 22 Tahun 2010 Tentang Rencana Tata Ruang Wilayah Provinsi Jawa Barat

Peraturan Daerah Kabupaten Garut Nomor 29 Tahun 2011 Tentang Rencana Tata Ruang Wilayah Kabupaten Garut Tahun $2011-2031$

Perka BKPM Nomor 14 Tahun 2015 Tentang Pedoman Dan Tata Cara Izin Prinsip Penanaman Modal

Perka BKPM Nomor 17 Tahun 2015 Tentang Pedoman Dan Tata Cara Pengendalian Pelaksanaan Penanaman Modal 
SK Gubernur Jawa Barat Nomor 561/Kep.1191-Bangsos/2016 Tentang Upah Minimum Kabupaten/Kota Di Daerah Propinsi Jawa Barat Tahun 2017

Peraturan Daerah Kabupaten Garut Nomor 14 Tahun 2012 tentang Penanaman Modal Peraturan Daerah Kabupaten Garut Nomor 9 Tahun 2016 tentang Pembentukan dan Susunan Perangkat Daerah Kabupaten Garut

Peraturan Bupati Kabupaten Garut Nomor 27 Tahun 2016 tentang Kedudukan dan Susunan Organisasi Perangkat Daerah Kabupaten Garut

Rencana Umum Penanaman Modal ( RUPM ) Dinas Penanaman Modal dan Perizinan Terpadu Kabupaten Garut Tahun 20182025

Rencana Strategis (Renstra) Dinas Penanaman Modal dan Perizinan Terpadu (DPMPT) Tahun 2017-2019 